\title{
11. TEXTURAL EVIDENCE OF DIAGENETIC EVOLUTION AT SITE 863, CHILE TRIPLE JUNCTION ${ }^{1}$
}

\author{
David J. Prior, ${ }^{2}$ Kathleen M. Marsaglia, ${ }^{3}$ E. Louise Rochford, ${ }^{2,4}$ Susan M. Agar, ${ }^{5}$ and Gordon Coy $^{6}$
}

\begin{abstract}
Microtextural studies show that vertically bedded sandstones drilled at ODP Site 863 have undergone at least two phases of diagenetic change. Early cements of intergrown filamentous smectites and euhedral $\mathrm{K} / \mathrm{Ca}$ zeolites are postdated by a later carbonate cement. Dissolution of clasts, most notably glassy volcanic lithics, is associated with the early diagenetic phase and may extend through to the later phase. Formation of Fe-sulfides occurs throughout the diagenetic evolution.

The early clay-zeolite cement partially or fully occludes pore spaces. Zeolites are rare at depths shallower than $408 \mathrm{mbsf}$. There is a sharp compositional change at $474 \mathrm{mbsf}$ from $\mathrm{K}$-rich clinoptilolites to more Ca-rich heulandites.

Carbonate cementation is strongly controlled by the pre-existing permeability, governed in turn by sandstone texture and the earlier clay-zeolite cementation. The carbonate preferentially cemented coarser, more permeable units and the cement has a dilational fracture morphology in siltstones and in many well-cemented sandstones. We postulate that the fluids that precipitated the carbonate in part generated their own transient permeability through fracture under high pore-fluid pressures.

The degree of diagenetic alteration observed at Site 863 is unique for a forearc site and is postulated to reflect the influence of the subducting mid-ocean ridge. The clear separation of the early clay-zeolite cements and the later carbonate cements may reflect two different fluid sources associated with the hydrothermal effects of ridge subduction upon an overlying forearc sedimentary sequence. It is postulated that the early clay-zeolite cements relate to continuing accretionary deformation and related circulation of accretionary fluids with the additional thermal effect of the subduction of the ridge or associated hot, young crust. Carbonate cementation may reflect penetration of the forearc by ridge related fluids.
\end{abstract}

\section{INTRODUCTION}

A general study of forearc sand and sandstone intervals cored during the Deep Sea Drilling Project indicates that clay mineral, zeolite, and carbonate cements are relatively rare in this tectonic setting (Marsaglia, 1989; Marsaglia and Ingersoll, 1992). Marsaglia (1989) found that out of 348 sandy intervals sampled, only $4 \%$ contain cements, and these occur at burial depths greater than $400 \mathrm{~m}$ and only in pre-Quaternary sections (Fig. 1). Subsequent drilling during the Ocean Drilling Program (ODP) confirms these trends. Site 863 of ODP Leg 141, near the Chile Triple Junction, is a remarkable exception to this trend. Here cemented Quaternary sandy turbidites were cored at relatively shallow depths ( $\geq 220$ meters below seafloor [mbsf]) and sandstones are very extensively cemented below about $400 \mathrm{mbsf}$. The unusual cementation almost certainly relates to the unique tectonic situation at Site 863. Here the forearc overlies an active, subducting mid-ocean ridge. Sediment compaction and forearc deformation are postdated by fluid flow and cementation that relate to the subducted mid-ocean ridge.

Site 863 comprises three structural domains (Behrmann, Lewis, Musgrave, et al., 1992); a complexly faulted domain overlies a gently dipping domain that in turn overlies a steeply dipping domain (Fig. 2).

\footnotetext{
'Lewis, S.D., Behrmann, J.H., Musgrave, R.J., and Cande, S.C. (Eds.), 1995. Proc. ODP, Sci. Results, 141: College Station, TX (Ocean Drilling Program).

${ }_{2}^{2}$ Department of Earth Sciences, University of Liverpool, P.O. Box 147, Liverpool L69 3BX. United Kingdom.

${ }^{3}$ Department of Geological Sciences, University of Texas at El Paso, El Paso, Texas 79968-0555, U.S.A.

${ }^{4}$ Present address: Department of Earth Sciences, University of Leeds, Leeds LS2 9JT, United Kingdom.

${ }^{5}$ Department of Geological Sciences, Northwestern University, Evanston, Illinois 60208, U.S.A.

${ }^{6}$ Department of Earth Sciences, University of Birmingham, Edgbaston, Birmingham B 15 2TT. United Kingdom.
}

There are abrupt changes in lithification with increasing depth. Silts, clays, and sands pass into siltstones, claystones, and sandstones at 104.4 mbsf, but most remarkable are changes in lithification within the steeply dipping domain. At Site 863, $484 \mathrm{~m}$ (258.8-742.9 mbsf) of vertically bedded, coarse turbidites, of Pleistocene age, were drilled with very good $(>50 \%)$ recovery (Fig. 2$)$. The depositional character of these sediments does not vary significantly down the hole (i.e., along strike with reference to bedding), yet there are changes in lithification and associated geochemical changes within this unit. There is an increase in lithification at 405.5 mbsf (Behrmann, Lewis, Musgrave, et al., 1992) that corresponds to observations of authigenic smectites, carbonates, and zeolites in smear slides and to a marked change in the ratios of clay minerals (Behrmann, Lewis, Musgrave, et al., 1992; Kurnosov et al, this volume). There is a correspondence between depth in the borehole and the quantity of authigenic calcite cement visible in the core (Behrmann, Lewis, Musgrave, et al., 1992). Shipboard pore-water analysis (Behrmann, Lewis, Musgrave, et al, 1992; Brown et al., this volume) has identified several geochemical fronts within the steeply dipping domain. The best developed of these corresponds to the lithification increase at $405.5 \mathrm{mbsf}$.

Samples from Site 863 provide a unique opportunity to evaluate the diagenetic history and corresponding permeability evolution at different distances from a fluid source. In most accretionary prisms, permeability evolution is intimately linked with compaction and tectonic deformation. Here we can examine an end member of the process of progressive porosity occlusion and the way this governs permeability, together with the permeability related feedback processes that may influence further adjustment of porosity. In this case, these processes are independent of compaction or deformation related modifications of porosity and pore interconnectivity. Furthermore, the turbidites comprise Bouma sequences with components of different grain size and texture. It is clear that these original parameters are important because the first mesoscopically visible cement is not developed homogeneously, but preferentially in the coarsest sand, concentrated in burrows and along the erosive bases of turbidites ( $\mathrm{Pl} .1$, Fig. 1). Thus, at Site 863 we have the opportunity to assess the influence of original texture and lithology on permeability evolution. 


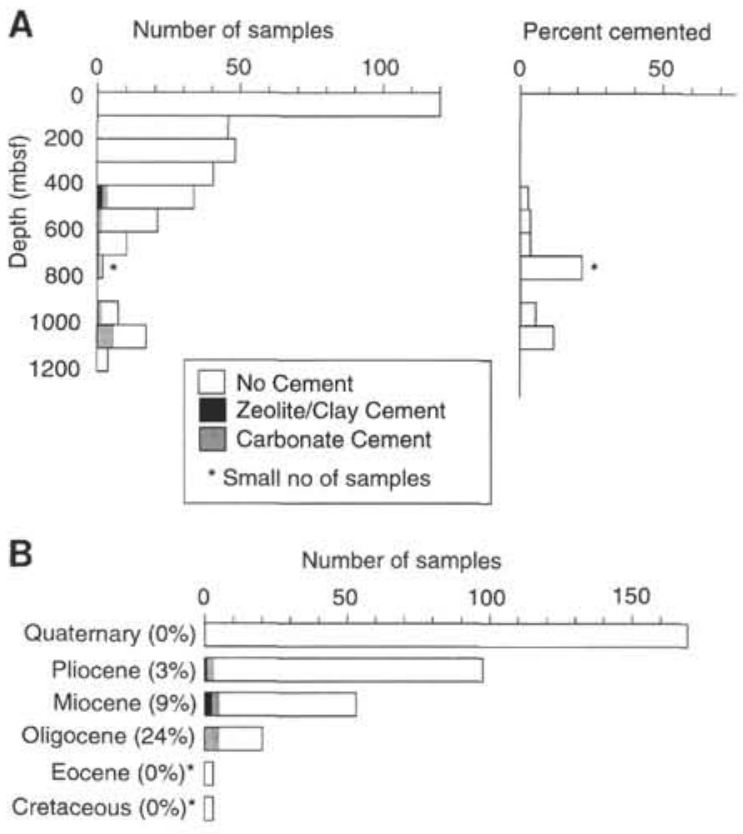

Figure 1. Histograms showing distribution of cemented/uncemented forearc samples with (A) depth and (B) by age, from Marsaglia (1989). Uncemented samples are unshaded, and cemented samples are shaded according to cement composition as shown in the key. The percentage of cemented samples for a given age or depth interval is illustrated to the right. For DSDP site and sample information see Marsaglia (1989) and Marsaglia and Ingersoll (1992).

\section{METHODS}

Specimens were sawn from the core and marked with the up-core orientation. Data from two sets of specimens are discussed in this paper.

Set 1: Sixty seven sandstone samples were first vacuum impregnated with blue-dyed epoxy prior to thin-section preparation in order to facilitate porosity recognition. Some thin sections were stained in order to distinguish potassium and calcium feldspars using a method outlined in Marsaglia and Tazaki (1992). This method also results in the etching and staining of $\mathrm{Ca}$ - and $\mathrm{K}$-bearing zeolites (see discussion in Marsaglia and Tazaki, 1992). Many samples were taken across cementation fronts to study the nature of these contacts.

All thin sections were petrographically examined (Table 1) for the presence of cements (zeolite, clay-mineral, carbonate) and grain dissolution textures (feldspar and volcanic glass). Selected samples were point-counted for grain and interstitial components (Table 2). Framework-grain data are presented and discussed in Marsaglia et al. (this volume).

Set 2: Aboard ship, samples were packed in double heat-sealed bags with a damp sponge in the outer bag to preserve moisture content. In the lab, specimens were trimmed with a precision annular saw and the selected specimen chips were vacuum impregnated with epoxy and made into stained and polished thin sections and polished specimen blocks. Selected specimens were broken into rough chips, air dried, and gold coated for examination with secondary electron (SE) microscopy. Twelve polished sections were examined optically, using fluorescence microscopy, scanning electron microscopy (SEM) and cathodoluminescence (CL) microscopy. A Camscan Series 4 SEM was used to collect SE images from rough specimens and backscattered electron (BSE) images from polished specimens, using a four quadrant solid-state detector. A beam current of $20 \mathrm{kV}$ was used with a working distance of 12-25 mm for most BSE imaging and for qualitative energy dispersive $\mathrm{X}$-ray $(\mathrm{EDX})$ analyses. Elemental ratios for analyses were measured from uncorrected spectra and are only of

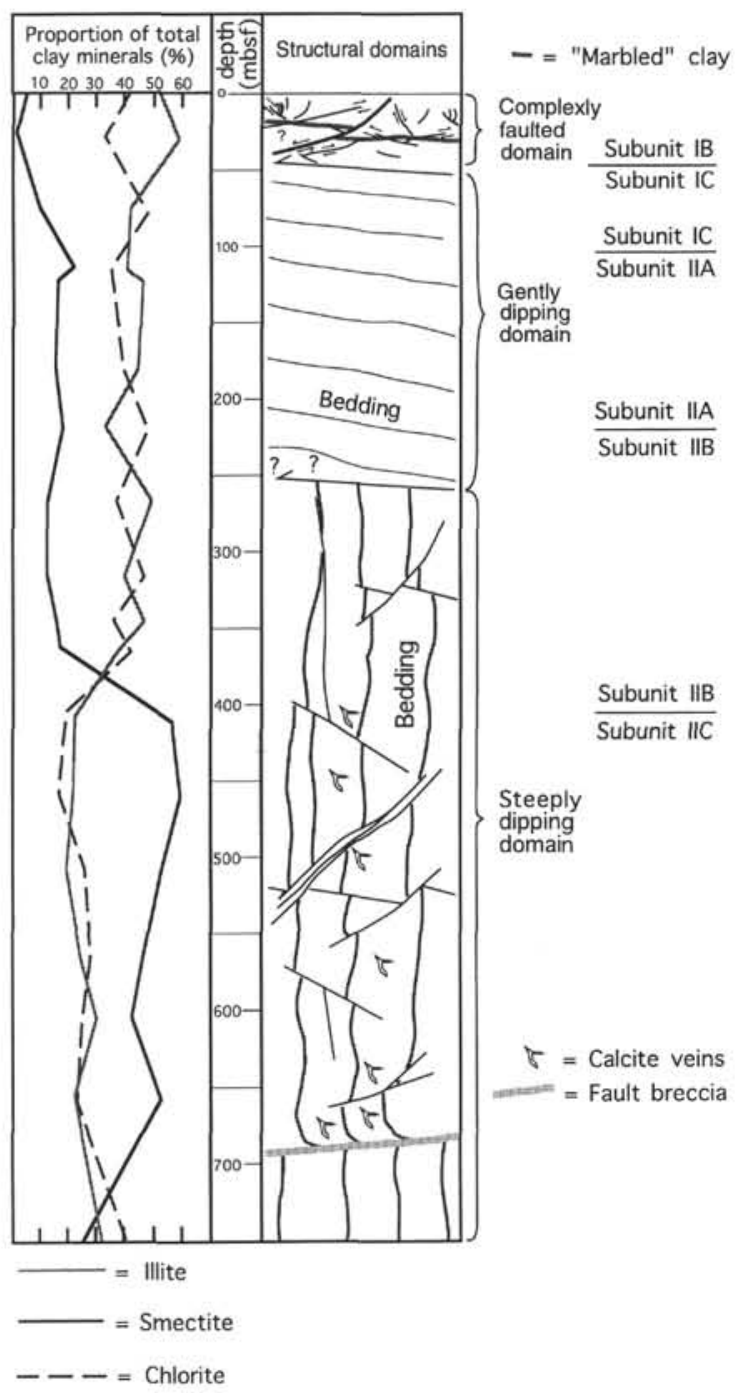

Figure 2. Main structural domains at Site 863 and summary of shipboard XRD clay mineral data (modified from Behrmann, Lewis, Musgrave, et al., 1992).

use for qualitative comparison of analysis of similar minerals. Some lower accelerating voltage (generally $10-12 \mathrm{kV}$ ) BSE imagery was carried out for improved spatial resolution. A summary of BSE observations is given in Table 3 .

Three-dimensional reconstruction of carbonate cement networks was completed by grinding the surface of a specimen block to remove 30 to $40 \mu \mathrm{m}$, imaging the specimen surface using CL microscopy, and then repeating this process until a representative number of layers had been collected. The carbonate distributions for each layer were digitized and the data stacked and displayed in a computer. It was found that this technique worked well for reconstruction of the geometries of carbonate cement, which images bright orange. The subtle contrasts between grains in CL images made the technique inappropriate for reconstructing grain geometries in three dimensions.

\section{TEXTURAL FRAMEWORK}

Sandy units in the less altered, more friable upper section shows diagenetic changes which include the dissolution of brown glassy groundmass within volcanic lithic fragments, minor feldspar dissolution, and rare, isolated carbonate nodules. Carbonate nodules are first observed at $76.4 \mathrm{mbsf}$ in a region characterized by poor recovery. At 
Table 1. Diagenetic parameters observed optically in samples from Site 863.

\begin{tabular}{|c|c|c|c|c|c|c|c|}
\hline $\begin{array}{l}\text { Core. section. } \\
\text { interval (cm) }\end{array}$ & $\begin{array}{l}\text { Depth } \\
\text { (mbsf) }\end{array}$ & $\begin{array}{l}\text { Glass } \\
\text { Diss }\end{array}$ & $\begin{array}{l}\text { Feld } \\
\text { Diss }\end{array}$ & $\begin{array}{l}\text { Carb } \\
\text { Cem }\end{array}$ & $\begin{array}{l}\text { Clay } \\
\text { Cem }\end{array}$ & $\begin{array}{l}\text { Zeol } \\
\text { Cem }\end{array}$ & Stain \\
\hline \multicolumn{8}{|l|}{$141-863 \mathrm{~A}-$} \\
\hline $3 \mathrm{H}-2,57-6 \mathrm{I}$ & 20.20 & $x$ & & & & & \\
\hline $7 \times-4.56-59$ & 61.15 & $\mathrm{x}$ & & & & & \\
\hline $24 X-1,10-12$ & 220.40 & & & $x$ & & & \\
\hline $28 \times-1.69-71$ & 259.40 & & & $\mathrm{x}$ & & & \\
\hline $28 \mathrm{X}-\mathrm{CC} .19-22$ & 260.25 & $\mathrm{x}$ & & & & & \\
\hline $29 \times-2.25-28$ & 269.45 & $\mathrm{X}$ & ? & & & & \\
\hline $30 x-1,3-7$ & 278.1 .3 & $\mathrm{x}$ & & & & & \\
\hline $31 \times-1.3-4$ & 287.63 & & & $\mathrm{x}$ & & ? & $\mathrm{R}$ \\
\hline $31 \times-1.41-43$ & 288.05 & $\mathrm{x}$ & ? & & & & \\
\hline \multicolumn{8}{|l|}{$141-863 \mathrm{~B}-$} \\
\hline $7 \mathrm{~N}-1.49-50$ & 355.40 & $\mathrm{x}$ & & & & & \\
\hline $7 \mathrm{~N}-2.14-16$ & 356.55 & $\mathrm{x}$ & $\mathrm{x}$ & & & & \\
\hline $7 \mathrm{~N}-\mathrm{CC} .4-6$ & 357.30 & $\mathrm{x}$ & & & & ? & $\mathrm{R}$ \\
\hline $8 \mathrm{~N}-1.5-7$ & 357.45 & $\dot{x}$ & & $x$ & & ? & $\mathrm{R}$ \\
\hline $8 \mathrm{~N}-1.56-58$ & 357.90 & $x$ & & & & & \\
\hline 10R-1. 68-71 & 371.68 & $\mathrm{x}$ & & $\mathrm{x}$ & $\mathrm{x}$ & & \\
\hline $12 \mathrm{R}-1,38-40$ & 386.68 & $\mathrm{x}$ & & $\dot{x}$ & & ? & R \\
\hline $12 \mathrm{R}-1.115-117$ & 387.45 & $\hat{x}$ & & & & & \\
\hline $\mid 3 R-1.41-43$ & 396.20 & $x$ & & & & $?$ & $\mathrm{R}$ \\
\hline $14 R-2,38-41$ & 407.40 & $\mathrm{x}$ & & & & & \\
\hline 14R-CC. $1-3$ & 408.60 & $x$ & $\mathrm{x}$ & $\mathrm{x}$ & & $x$ & RY \\
\hline I5R-I. I-3 & 415.21 & $\mathrm{x}$ & & $\mathrm{x}$ & & $\mathrm{x}$ & RY \\
\hline $15 R-1.85-89$ & 416.05 & $\mathrm{x}$ & & & $\mathrm{x}$ & $\mathrm{x}$ & NS \\
\hline $16 R-2.46-48$ & 426.60 & $\mathrm{x}$ & $\mathrm{x}$ & $\mathrm{x}$ & & $\mathrm{x}$ & NS \\
\hline $16 R-4.130-133$ & 430.50 & $x$ & & $\mathrm{x}$ & & $x$ & RY \\
\hline $16 R-5,51-55$ & 431.20 & $\mathrm{x}$ & $x$ & & & $\hat{x}$ & NS \\
\hline 17R-6. 96-99 & 442.86 & $\mathrm{x}$ & $\mathrm{x}$ & $\mathrm{x}$ & & $\mathrm{x}$ & NS \\
\hline $17 R-7.20-25$ & $44,3.10$ & $\mathrm{x}$ & & & $\mathrm{x}$ & $x$ & RY \\
\hline $18 R-1.106-109$ & 445.06 & $\mathrm{x}$ & & $\mathrm{x}$ & & $\mathrm{x}$ & NS \\
\hline $18 R-3,60-62$ & 447.60 & $\mathrm{x}$ & & $\mathrm{x}$ & & $x$ & NS \\
\hline $19 R-1.25-28$ & 453.90 & $\ddot{x}$ & $\mathrm{x}$ & $\hat{x}$ & & $\dot{x}$ & NS \\
\hline $19 R-3,102-105$ & 457.75 & $\mathrm{x}$ & $x$ & $\mathrm{x}$ & & $\mathrm{x}$ & RY \\
\hline 20R-CC. $12-14$ & 466.60 & $\mathrm{x}$ & $x$ & $x$ & & $?$ & NS \\
\hline 2 IR-1.72-75 & 473.70 & $\ddot{x}$ & $\hat{x}$ & $\ddot{x}$ & & $x$ & $R Y \& R$ \\
\hline 2 IR-2. $16-20$ & 474.25 & $\hat{x}$ & $\hat{x}$ & $\hat{x}$ & & $\hat{x}$ & NS \\
\hline $22 \mathrm{R}-1.81-83$ & 483.50 & $\mathrm{x}$ & $x$ & $\mathrm{x}$ & $\mathrm{x}$ & R & \\
\hline $23 R-3,38-41$ & 495.70 & $\ddot{x}$ & $\hat{x}$ & $\hat{x}$ & $\hat{x}$ & $\ddot{x}$ & NS \\
\hline $24 R-3,11-13$ & 505.10 & $\mathrm{x}$ & & & $x$ & $\mathrm{x}$ & $\mathrm{R}$ \\
\hline $25 R-1.65-67$ & 512.30 & $\mathrm{x}$ & $\mathrm{x}$ & $\mathrm{x}$ & $\mathrm{x}$ & $\mathrm{N}$ & $\mathrm{S}$ \\
\hline $25 \mathrm{R}-2,111-114$ & 514.30 & $\hat{x}$ & $\hat{x}$ & $\hat{x}$ & & $\mathrm{x}$ & $\mathrm{R}$ \\
\hline $25 \mathrm{R}-3,49-52$ & 515.20 & $\hat{x}$ & $\hat{x}$ & $\hat{x}$ & & $\hat{x}$ & NS \\
\hline $25 \mathrm{R}-4,36-39$ & 516.50 & $x$ & $\hat{x}$ & & & $x$ & NS \\
\hline $27 \mathrm{R}-3.8-11$ & 533.70 & $\mathrm{x}$ & $x$ & & $?$ & $\mathrm{x}$ & $\mathrm{R}$ \\
\hline $3 \mid R-4,40-43$ & 574.00 & $\mathrm{x}$ & $\mathrm{x}$ & $x$ & & $\mathrm{x}$ & NS \\
\hline $32 \mathrm{R}-5,38-40$ & 585.10 & $x$ & $\dddot{z}$ & $\ddot{x}$ & $x$ & $\dot{x}$ & $R \& R Y$ \\
\hline $33 R-1,49-51$ & 588.90 & $\hat{x}$ & $\dot{x}$ & & $N^{2}$ & $\hat{x}$ &  \\
\hline $34 R-5.70-73$ & 604.70 & $x$ & & & $x$ & $\ddot{x}$ & $\mathrm{R}$ \\
\hline $35 \mathrm{R}-1.4-6$ & 608.10 & $\mathrm{x}$ & & $?$ & $\hat{x}$ & $\mathrm{R}$ & \\
\hline $36 \mathrm{R}-1.11-13$ & 617. & $\mathrm{x}$ & $x$ & $\mathrm{x}$ & & & \\
\hline $36 \mathrm{R}-2,45-47$ & 619.30 & $\mathrm{x}$ & $\mathrm{x}$ & $\mathrm{x}$ & $\mathrm{x}$ & $\mathrm{x}$ & NS \\
\hline $36 \mathrm{R}-3,70-73$ & 620.60 & $\mathrm{x}$ & $\mathrm{x}$ & & ? & $\mathrm{x}$ & \\
\hline $37 R-4.77-80$ & 632.20 & $\hat{x}$ & $\hat{x}$ & & $\dot{x}$ & $\hat{x}$ & R \\
\hline $38 \mathrm{R}-1.69-72$ & 637.30 & $\mathrm{x}$ & $?$ & & ? & $?$ & NS \\
\hline $38 R-3,95-97$ & 640.50 & $\hat{x}$ & $\dot{x}$ & & & $\dot{x}$ & NS \\
\hline $39 \mathrm{R}-2,105-107$ & 648.70 & $x$ & $\mathrm{x}$ & $x$ & $x$ & $\mathrm{x}$ & $R$ \\
\hline $42 R-1,0-2$ & 675.20 & $\hat{x}$ & & $\hat{x}$ & & $\hat{x}$ & NS \\
\hline $42 R-2,62-64$ & 677.30 & $\mathrm{x}$ & $\mathrm{x}$ & $\mathrm{x}$ & & $\mathrm{x}$ & $\mathrm{R}$ \\
\hline $43 \mathrm{R}-2,41-43$ & 686.70 & $x$ & $\mathrm{x}$ & & & & \\
\hline $43 \mathrm{R}-2.73-75$ & 687.00 & $\hat{x}$ & & & & $\mathrm{x}$ & $\mathrm{XR}$ \\
\hline $44 R-3,132-135$ & 698.80 & $\mathrm{x}$ & $\mathrm{x}$ & $\mathrm{x}$ & $\mathrm{x}$ & $\mathrm{x}$ & NS \\
\hline $44 R-5,43-46$ & 700.70 & $x$ & $\hat{x}$ & & & & \\
\hline $45 \mathrm{R}-1,32-36$ & 704.50 & $\hat{x}$ & $\hat{x}$ & $\mathrm{x}$ & $\mathrm{x}$ & $x$ & NS \\
\hline $46 \mathrm{R}-2,62-66$ & 708.90 & $\mathrm{x}$ & $\mathrm{x}$ & & & $\mathrm{x}$ & $\mathrm{R}$ \\
\hline $47 R-1,111-122$ & 714.9 & $x$ & $\mathrm{x}$ & $\mathrm{x}$ & & $x$ & $\mathrm{R}$ \\
\hline $47 \mathrm{R}-2,32-36$ & 715,60 & ?" & $\hat{x}$ & $\hat{x}$ & $x$ & $\hat{x}$ & NS \\
\hline 47R-CC. $18-21$ & 717.70 & $\mathrm{x}$ & $\mathrm{x}$ & $\mathrm{x}$ & $\mathrm{x}$ & & \\
\hline $48 \mathrm{R}-3,4 \mathrm{l}-4,3$ & 725.20 & $\hat{x}$ & $\hat{x}$ & & $\ddot{x}$ & & \\
\hline $49 \mathrm{R}-1.86-89$ & 734.00 & $\mathrm{x}$ & $\mathrm{x}$ & $\mathrm{x}$ & & & \\
\hline
\end{tabular}

Note: A $\cdots \cdots$ in zeolite cement column indicates that a mineral was stained: this could have been gypsum. $R=$ red stain $(\mathrm{Ca}) ; \mathrm{RY}=$ red/yelow stain $(\mathrm{K})$ : NS = no stain. $A$ $\cdots \cdot *$ in columns other than zeolite suggests some uncertainty in mineral identification. Significant changes in cementation are observed at 408 and 478 mbsf.

greater depths (up to $357 \mathrm{mbsf}$ ) carbonate nodules were recovered only in the first few centimeters of some cores and are probably debris from a nodule-rich layer higher in the hole (at approximately $75 \mathrm{mbsf}$ ).

Most of the data presented in this paper relate to the steeply dipping domain ( $>259 \mathrm{mbsf}$ ). The vertically bedded turbidites sampled at Site 863 range from sand/sandstones to silty clay/claystones. Only sand and sandstone samples were examined in this study. These are coarse to fine, very immature wackes. The dominant grain types are plagioclase feldspar, quartz, and volcanic lithic clasts, but relative abundances vary enormously (Marsaglia et al., this volume). Other components include amphibole, epidote, biotite, pyroxene, and opaque minerals. Carbonate, clay, and zeolite cements and vein infill- 
Table 2. Optical point count data for sandstones from Site 863 .

\begin{tabular}{|c|c|c|c|c|c|c|c|c|c|c|c|}
\hline $\begin{array}{l}\text { Core, section. } \\
\text { interval (cm) }\end{array}$ & $\begin{array}{l}\text { Depth } \\
\text { (mhsf) }\end{array}$ & $\begin{array}{c}\text { Frame } \\
\text { work } \\
\text { grains }\end{array}$ & $\begin{array}{l}\text { Mutrix } \\
\text { silt }\end{array}$ & $\begin{array}{c}\text { Matrix } \\
\text { clay }\end{array}$ & $\begin{array}{l}\text { Inter-particulate } \\
\text { porosity }\end{array}$ & $\begin{array}{c}\text { Carbonate } \\
\text { cement }\end{array}$ & $\begin{array}{c}\text { Clay } \\
\text { cement }\end{array}$ & $\begin{array}{c}\text { Red } \\
\text { zeolite } \\
\text { cement }\end{array}$ & $\begin{array}{l}\text { Red/ } \\
\text { yellow } \\
\text { zeolite } \\
\text { cement }\end{array}$ & $\begin{array}{l}\text { Authigenic } \\
\text { opaques }\end{array}$ & $\begin{array}{l}\text { Total } \\
\text { points }\end{array}$ \\
\hline \multicolumn{12}{|l|}{$141-863 \mathrm{~A}=$} \\
\hline $28 \times-1.69-71$ & 259.40 & 400 & 21 & 20 & 4 & 158 & 0 & 5 & 0 & 3 & 611 \\
\hline $28 \times-C C .19-22$ & 260.25 & 400 & 129 & 87 & 0 & 0 & 2 & 0 & 0 & 4 & 622 \\
\hline $31 X-1.3-4$ & 287.63 & 400 & 75 & 37 & 0 & 267 & $\overline{0}$ & 8 & 0 & i & 788 \\
\hline \multicolumn{12}{|l|}{$141-863 \mathrm{~B}=$} \\
\hline $7 \mathrm{~N}-\mathrm{CC} \cdot 4-6$ & 357.30 & 400 & 73 & 49 & 44 & 0 & 0 & 1 & 0 & 1 & 568 \\
\hline $8 \mathrm{~N}-1,5-7$ & 357.45 & 400 & 16 & 2 & 1 & 122 & 2 & 36 & 0 & 5 & 584 \\
\hline $10 R-1.68-71$ & 371.68 & 400 & 26 & 23 & 0 & 6.5 & 2 & 0 & 0 & 3 & 519 \\
\hline $12 R-1.38-40$ & 386.68 & 400 & 14 & 0 & 0 & 117 & 2 & 2 & 0 & 0 & 535 \\
\hline $13 R-1,41-43$ & 396.20 & 400 & 116 & 155 & 33 & 0 & 0 & 2 & 0 & 2 & 708 \\
\hline $15 R-1,1-3$ & 415.21 & 400 & () & 13 & 0 & 3 & 0 & 0 & 20 & 10 & 446 \\
\hline $16 \mathrm{R}-4.130-133$ & 430.50 & 400 & 15 & 0 & 4 & 94 & 0 & 0 & 41 & 1 & 555 \\
\hline $17 R-7.20-25$ & 443.10 & 300 & 96 & 15 & 0 & 0 & 0 & 0 & 5 & i & 417 \\
\hline $2 I R-1.72-75$ & 473.70 & 400 & 45 & 4 & 3 & 85 & 5 & 15 & 18 & i & 576 \\
\hline $22 \mathrm{R}-1.81-83$ & 483.50 & 400 & 123 & 56 & 23 & 0 & 84 & 1 & 0 & 0 & 687 \\
\hline $24 R-3 . \mid 1-13$ & 505.10 & 400 & 160 & 26 & 41 & 0 & 54 & 14 & 0 & 9 & 704 \\
\hline $32 R-5,38-40$ & 585.10 & 267 & () & () & 25 & 6 & 9 & 41 & 1 & 4 & 353 \\
\hline $34 \mathrm{R}-5,70-73$ & 604.70 & 400 & $7 \ddot{~}$ & 25 & 39 & 0 & 11 & 33 & 0 & 0 & 579 \\
\hline $37 R-4.77-80$ & 6.32 .20 & 400 & 128 & 4 & 37 & 2 & 16 & 38 & 0 & 0 & 625 \\
\hline $39 R-2.105-107$ & 648.70 & 285 & 0 & 27 & 24 & $i$ & 19 & 44 & 0 & 0 & 400 \\
\hline $42 \mathrm{R}-2.62-64$ & 677.30 & 400 & 48 & 22 & 19 & () & 36 & 40 & 0 & 2 & 567 \\
\hline $43 R-2.73-75$ & 687.00 & $4(x)$ & 70 & 149 & 2 & 0 & 1 & 34 & 0 & 0 & 656 \\
\hline $46 R-2.62-66$ & 708.90 & 400 & 47 & 3 & 10 & 0 & 6 & 55 & 0 & 3 & 524 \\
\hline $47 \mathrm{R}-1.111-122$ & 714.90 & 290 & 0 & 16 & 0 & 64 & 0 & 26 & 0 & 5 & 401 \\
\hline
\end{tabular}

Note: This table does not subdivide grain populations, authigenic, and matrix components. For point count data of grain populations see Marsaglia et al. (this volume).

\begin{tabular}{|c|c|c|c|c|c|c|c|c|c|c|}
\hline $\begin{array}{l}\text { Core. section. } \\
\text { interval }(\mathrm{cm})\end{array}$ & $\begin{array}{l}\text { Carbonate } \\
\text { cement } \\
\text { (\%) }\end{array}$ & $\begin{array}{c}\text { Clay } \\
\text { cement } \\
(\%)\end{array}$ & $\begin{array}{c}\text { Red } \\
\text { zeolite } \\
\text { cement } \\
(\%)\end{array}$ & $\begin{array}{l}\text { Red/ } \\
\text { yellow } \\
\text { reolite } \\
\text { cement }\end{array}$ & $\begin{array}{l}\text { Authigenic } \\
\text { opaques } \\
(\%)\end{array}$ & $\begin{array}{c}\text { Total } \\
\text { matrix } \\
(\%)\end{array}$ & $\begin{array}{c}\text { Total } \\
\text { cement } \\
(\%)\end{array}$ & $\begin{array}{c}\text { Total } \\
\text { porosity } \\
(\%)\end{array}$ & $\begin{array}{l}\text { Total } \\
\text { cement } \\
\text { and } \\
\text { porosity } \\
\text { (\%) }\end{array}$ & $\begin{array}{l}\text { IGV } \\
(\%)\end{array}$ \\
\hline \multicolumn{11}{|l|}{$141-863 \mathrm{~A}-$} \\
\hline $28 \times-1.69-71$ & 26 & 0) & 1 & 0 & 0 & 7 & 27 & 1 & 28 & 35 \\
\hline $28 \times-C C .19-22$ & 0 & 0 & 0 & 0 & 1 & 35 & 1 & 0 & 1 & 36 \\
\hline $31 \times-1.3-4$ & 34 & 0 & 1 & 0 & 0 & 14 & 35 & 0 & 35 & 49 \\
\hline \multicolumn{11}{|l|}{$141-86.3 \mathrm{~B}-$} \\
\hline 7 N-CC. $4-6$ & 0 & 0 & 0 & 0 & 0 & 21 & 0 & 8 & 8 & 30 \\
\hline $8 \mathrm{~N}-1,5-7$ & 21 & 0 & 6 & 0 & i & 3 & 28 & 0 & 28 & 32 \\
\hline $10 R-1.68-71$ & 13 & 0 & 0 & 0 & i & 9 & 13 & 0 & 13 & 23 \\
\hline $12 \mathrm{R}-1.38-40$ & 22 & 0 & 0 & 0 & 0 & 3 & 23 & 0 & 23 & 25 \\
\hline $13 R-1.41-43$ & 0 & () & 0 & 0 & 0 & 38 & 1 & 5 & 5 & 44 \\
\hline $15 \mathrm{R}-1.1-3$ & 1 & 0 & 0 & 4 & 2 & 3 & 7 & 0 & 7 & 10 \\
\hline $16 R-4.130-133$ & 17 & 0 & 0) & 7 & 0 & 3 & 25 & 1 & 25 & 28 \\
\hline $17 \mathrm{R}-7.20-25$ & 0 & 0 & 0 & 1 & 0 & 27 & 1 & 0 & 1 & 28 \\
\hline $21 \mathrm{R}-1.72-7.5$ & 15 & 1 & 3 & 3 & 0 & 9 & 22 & 1 & 22 & 31 \\
\hline $22 \mathrm{R}-1.81-83$ & 0 & 12 & 0 & () & 0 & 26 & 12 & 3 & 16 & 42 \\
\hline $24 R-3,11-13$ & 0 & 8 & 2 & 0 & 1 & 26 & 11 & 6 & 17 & 43 \\
\hline $32 R-5,38-40$ & 2 & 3 & 12 & 0 & i & 0 & 17 & 7 & 24 & 24 \\
\hline $34 R-5,70-73$ & 0 & 2 & 6 & 0 & 0 & 17 & 8 & 7 & 14 & 31 \\
\hline $37 R-4.77-80$ & 0 & 3 & 6 & 0 & 0 & 21 & 9 & 6 & 15 & 36 \\
\hline $39 \mathrm{R}-2,105-107$ & 0 & 5 & 11 & 0 & 0 & 7 & 16 & 6 & 22 & 29 \\
\hline $42 \mathrm{R}-2.62-64$ & 0 & 6 & 7 & 0 & 0 & 12 & 14 & 3 & 17 & 29 \\
\hline $43 R-2.73-7.5$ & () & 0 & 5 & 0 & 0 & 33 & 5 & 0 & 6 & 39 \\
\hline $46 R-2.62-66$ & 0 & 1 & 10 & 0 & 1 & 10 & 12 & 2 & 14 & 24 \\
\hline $47 \mathrm{R}-1.111-122$ & 16 & 0 & 6 & 0 & i & 4 & 24 & () & 24 & 28 \\
\hline
\end{tabular}

ings and authigenic Fe-sulfides were identified in the core and in smear slides collected on ship (Behrmann, Lewis, Musgrave, et al., 1992). Dissolution of clastic components is also important. The distribution of selected authigenic phases and dissolution textures identified by onshore optical studies is shown in Table 1 and from BSE studies in Table 3. Fe-sulfides and dissolution of heavy mafic minerals are not shown, but occur sporadically throughout the section.

Detrital modes indicate that relatively soft shale/mudstone fragments are a common component of these sandstones. These labile constituents are commonly deformed and squashed into pseudomatrix. Some of the clay and Fe-sulfide cement phases are involved in the deformation of labile phases, which suggests that sandstones from Site 863 underwent various degrees of compaction prior to and during cementation. Generally compaction significantly decreases inter- granular volumes (IGV) prior to cementation (Pl. 2, Fig. 1). IGV's are in the $10 \%-50 \%$ range, with most data between $20 \%$ and $40 \%$. There is no clear relationship between IGV's and depth (Fig. 3), although high matrix values make IGV data less valuable. Maximum values of total cement + porosity (precementation porosity) decrease with depth (Fig. 3) suggesting that there may have been some component of compaction post-dating the tilting to vertical and predating the observed cementation.

\section{Clay Cements}

Shipboard X-ray diffraction (XRD) analyses (Behrmann, Lewis, Musgrave, et al., 1992) identified downhole changes in relative proportions of the phyllosilicate phases. These data are supported by a 
Table 3. Table showing the main authigenic phases observed using BSE images on the SEM.

\begin{tabular}{|c|c|c|c|c|c|c|c|}
\hline $\begin{array}{l}\text { Core. section. } \\
\text { interval (cm) }\end{array}$ & $\begin{array}{l}\text { Depth } \\
\text { (mbsf) }\end{array}$ & Carb. & III. & III/Sm. & $\begin{array}{l}\text { Hairy } \\
\text { Sm. }\end{array}$ & Nontr. & Clin. \\
\hline \multicolumn{8}{|l|}{$141-863 \mathrm{~B}-$} \\
\hline IOR-1. 75-77 & 372 & Zoned & $\mathrm{Y}$ & $\mathrm{Y}$ & & $Y$ & \\
\hline $10 R-1.105-107$ & 372 & & & & & & \\
\hline IIR-1.33-35 & 377 & & & & & & \\
\hline 13R-CC. $54-10$ & 405 & $\mathrm{Y}$ & & $Y$ & $\mathrm{Y}$ & & \\
\hline $15 R-2.121-128$ & 417 & & & & & & \\
\hline $\mid 6 R-2.49-51$ & 427 & $\mathrm{Y}$ & & & $\mathrm{Y}$ & & $\mathrm{Y}$ \\
\hline $16 \mathrm{R}-3.109-112$ & 429 & & & & & & \\
\hline $17 R-2.123-125$ & 438 & & & & & & \\
\hline $31 \mathrm{R}-3.30-33$ & 572 & $\mathrm{Y}$ & & & $\mathrm{Y}$ & & $\mathrm{Y}$ \\
\hline $36 \mathrm{R}-3,63-71$ & 620 & & & & $\mathrm{Y}$ & & $\mathrm{Y}$ \\
\hline $37 \mathrm{R}-1.54-59$ & 628 & & & & $\mathrm{Y}$ & ? & $\mathrm{Y}$ \\
\hline $41 R-2.119-126$ & 670 & $\mathrm{Y}$ & & & & & $?$ \\
\hline
\end{tabular}

Note: More than one specimen was made from many samples. Carb. = carbonate cement. III. = illitic clay as a cement. III/Sm, = mixed layer clays as a cement. Hairy $\mathrm{Sm} .=$ filamentous smectites as a cement. Nontr. $=$ nontronite. Clin. $=$ clinoptilolite .

more complete data set presented by Kurnosov et al. (this volume). Down to about 370 mbsf the dominant clay mineral is illite $(>40 \%)$ with smectite comprising less than $25 \%$ of the total phyllosilicate content (Fig. 2). Between 395.92 and 417.46 mbsf there is a dramatic change with smectite increasing to greater than $50 \%$ and illite dropping to less than $30 \%$. Chlorite content mirrors that of the illite. One difficulty in the textural analysis of sediments is distinguishing authigenic clay cements precipitated from fluid, from the matrix clays that are part of the clastic assemblage. A further problem lies in ascertaining whether matrix clays represent an original sedimentary component or a diagenetic alteration thereof. In optical studies clay cements are distinguished from matrix clays based on their uniform fine-grained appearance and in some cases on the basis of their pore lining morphology. On this basis the clay cements are first identified at $372 \mathrm{mbsf}$ and become more abundant below 474 mbsf (Tables 1 and 2). Using electron microscopic techniques it is often possible to distinguish cement clays from clays related to alteration of matrix components and original matrix clays on the basis of their textures. BSE data are discussed below.

In the shallowest specimen examined using BSE ( $372 \mathrm{mbsf}$ ), the main phyllosilicate phases are large $(10-30 \mu \mathrm{m})$ with a well-defined cleavage and a blocky shape (Pl. 1, Fig. 2). BSE images show that there are two discrete compositions and that some of these are intergrown on the micrometer scale to form compositionally layered phyllosilicates (Pl. 1, Fig. 3). The spatial distribution of these phyllosilicates outlines ghost clasts (PI. 1, Fig. 2) and we interpret these as remnants of compacted and altered clasts. Some finer phyllosilicates are located along the contacts of the "ghost clasts." Finer grained clays are associated spatially with volcanic clasts (Pl. 1, Fig. 4). These generally comprise randomly oriented filaments less than a micrometer in thickness and up to a few micrometers in length.

In the next deepest specimen examined using BSE ( $427 \mathrm{mbsf}$ ) and all deeper specimens, clays are found in pore spaces. Clays commonly form thin mantles on clasts neighboring porosity (Pl. 1, Figs. 4-6). The clays form delicate filaments, up to $5 \mu \mathrm{m}$ long and less than a micrometer wide, or aggregates of filaments with thicknesses up to $2 \mu \mathrm{m}$ (Pl. 1, Fig. 5). The clays are typically oriented at high angles to grain contacts and have the appearance of tentacles, grown into porosity from clast edges. Some clay filaments act as bridges across the porosity between clasts and as bridges to associated zeolite crystals (PI. 1, Figs. 4 and 5). Clays with these morphological features described above are interpreted as cement phases. Deeper at Site 863 pore spaces are reduced and the proportion of fine-grained clays increases. Occlusion by clays and associated zeolites is almost complete (Pl. 1, Fig. 7; Pl. 2, Fig. 1; Pl. 2, Fig. 2), although the pore spaces that were observed are lined with filamentous clays with textures identical to those higher in the hole. Pore-lining and pore-occluding clays are not easily distinguishable on the basis of BSE intensity.

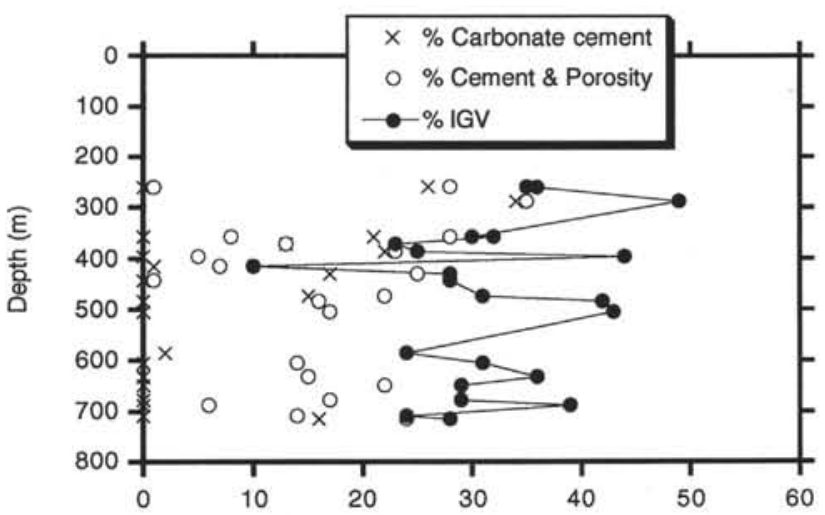

Figure 3. Plots of percentages of intergranular volumes (IGV), total cement and porosity, and carbonate cement with depth at Site 863. Data are from optical point counts (Table 2).

EDX analyses of fine-grained clays using an SEM are problematic. The activation volume for X-ray fluorescence (XRF; Goldstein et al., 1981) is of the same order as the size of individual filaments, so that analyses are likely to include more than one filament and any interstitial impurities such as grain interface coatings, epoxy-filled porosity, and other minerals. Without conducting transmission electron microscopy (TEM) work (Smart and Tovey, 1987) only qualitative analyses are possible. In this study all EDX analyses of clays were of filamentous bundles to minimize the proportion of interstitial material.

Analyses of pore-filling filamentous clays show considerable variation at all depths (Fig. 4). Analyses of filamentous clays related to alteration of clasts fall within the range of pore-filling clay analyses. Filamentous clays are broadly smectitic with $\mathrm{Al} / \mathrm{Si}$ ratios of 0.16 to 0.41 (Fig. 5) and considerable variation in $\mathrm{Fe}, \mathrm{Ca}$, and $\mathrm{K}$ contents (Fig. 5 ). This study and bulk chemistry of the $<1 \mathrm{~mm}$ fraction (Kurnasov et al., this volume) suggest that the clays are generally more Fe-rich throughout than ideal smectites (Güven, 1988); many are similar in composition to nontronite (Welton, 1984). Little Na was detected in many specimens, although this may relate to the insensitivity of EDX analyses to $\mathrm{Na}$ (Goldstein et al., 1981). $\mathrm{Fe}$ and $\mathrm{Mg}$ contents vary sympathetically, whereas $\mathrm{K}$ and $\mathrm{Ca}$ contents and $\mathrm{Na}$ and $\mathrm{Mg}$ contents do not (Fig. 6). There is no systematic variation in $\mathrm{Al} / \mathrm{Si}$ or $\mathrm{K} / \mathrm{Si}$ ratios of filamentous clays down the hole. $\mathrm{Fe} / \mathrm{Si}, \mathrm{Mg} / \mathrm{Si}, \mathrm{Ca} / \mathrm{Si}$, and $\mathrm{Na} / \mathrm{Si}$ show a bigger range at greater depth but this may relate to a larger sample. Euhedral/subhedral phyllosilicates, found only in the shallowest specimen examined, have distinct $\mathrm{Al} / \mathrm{Si}(0.61-0.8)$ and $\mathrm{K} / \mathrm{Si}$ ratios (Figs. 4 and 5) compared to filamentous clays. These are mixed layer illite/smectites. 

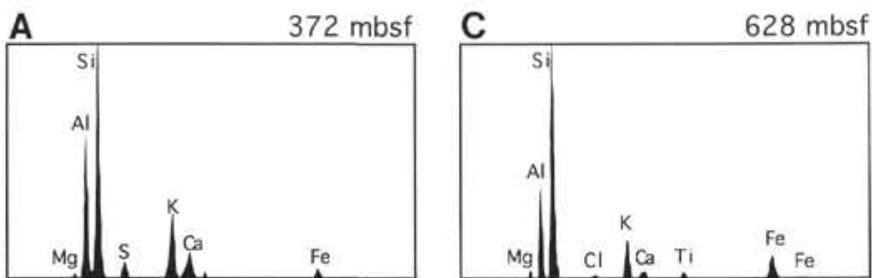

B
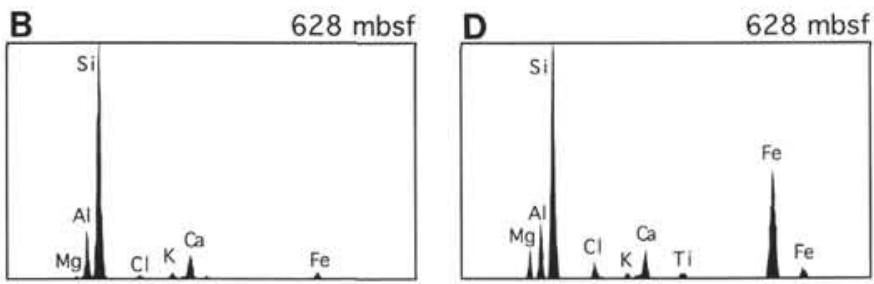

Figure 4. Examples of EDX spectra for (A) one illite-smectite and $(\mathbf{B}, \mathbf{C}, \mathbf{D})$ a variety of smectite analyses. All the smectite analyses are from the same sample and are typical of the range of smectite analyses at all depths. Spectra have been normalized so that the silica peaks have the same height. Sample A: 141-863B-10R-1, 75-77 cm; Samples B, C, D: 141-863B-37R-1, 54-59 cm.
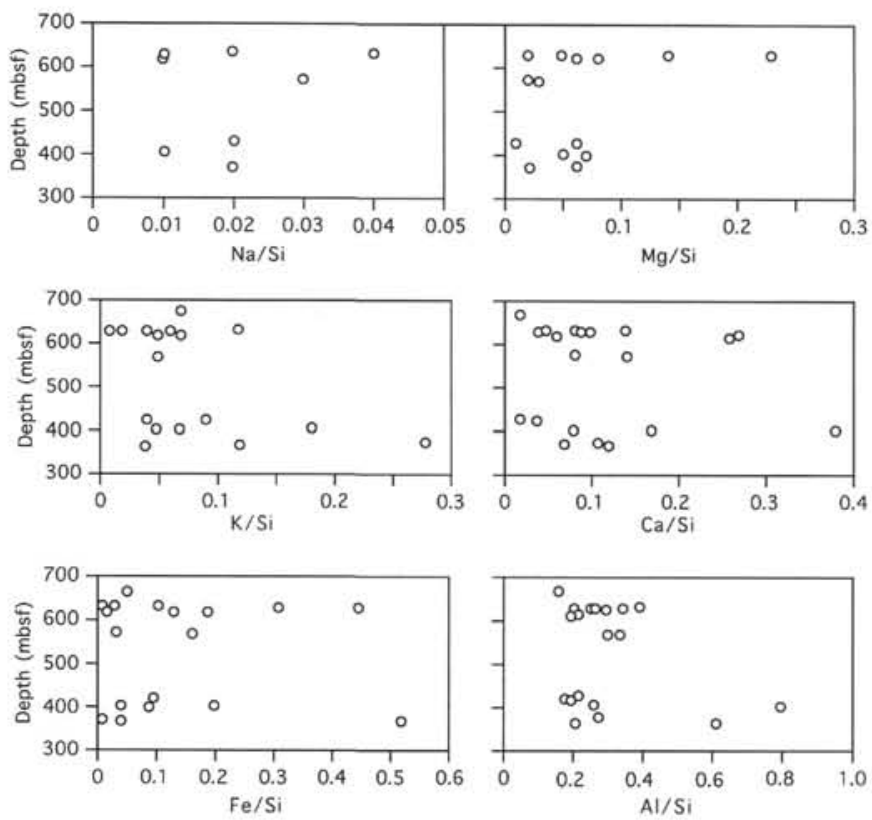

Figure 5. Peak height ratios (taken from EDX analyses of seven samples) plotted against depth.

\section{Zeolite Cements}

Shipboard studies showed that some sandstones were cemented with zeolites. Zeolites can be identified optically and in BSE images. Zeolites are identified in most specimens below 407.4 mbsf and are very rare at shallower depths. They are found in pore spaces and are intimately associated with pore-filling filamentous clays. Zeolites are characterized by euhedral laths, commonly intergrown with neighboring laths to produce irregular aggregates (Pl. 1, Figs. 4-6). SE images (Pl. 3, Figs. 1 and 2) clearly show bricklike and rhombohedral morphologies. Zeolites are suspended in pore spaces by bridges of filamentous clays (Pl. 1, Figs. 4-6; Pl. 3, Fig. 1). Some clay/zeolite cements show a zoning pattern in which a pore-filling cement in contact with grains comprises entirely clay minerals and is superseded by a zeolite-dominated cement (PI. 2, Fig. 4).

Two types of zeolite can be distinguished optically, in thin sections stained for K- and Ca-feldspar. In specimens shallower than $474 \mathrm{mbsf}$


Figure 6. Cross-plots of peak heights (taken from EDX analyses) for data shown in Figure 5. All peak heights measured are for the same $60 \mathrm{~s}$ count time.

the zeolites take either a red stain or both red and yellow stains, whereas those deeper than 474 mbsf stained red. Point-count data show that red stained zeolites are rare between 259 and $474 \mathrm{mbsf}$ and are most abundant below $474 \mathrm{mbsf}$ (Table 2). Red/yellow stained zeolites are most abundant at intermediate depths (415-474 mbsf). EDX analyses show that zeolites at $427 \mathrm{mbsf}$ are dominantly potassic (Fig. 7), whereas those deeper in the hole $(572,620$, and $628 \mathrm{mbsf})$ are dominantly calcic (Fig. 7). This suggests that the relationship of stain uptake to composition of zeolites mirrors that for feldspars; $\mathrm{Ca}$ zeolites stain red whereas $\mathrm{K}$ zeolites stain yellow. Zeolites from deeper sections have higher $\mathrm{Al} / \mathrm{Si}$ ratios $(0.25-0.34)$ compared with the shallower ones $(0.18-0.19)$. The potassic zeolites, from the upper section, correspond compositionally and morphologically to clinoptilolite (Schaller, 1932; Welton, 1984). Deeper zeolites are closer to heulandite in composition. The observed compositions most likely represent a solid-solution series (Hey and Bannister, 1934), although the staining data suggests that the compositional change within the series with depth is quite sharp (Table 1). XRD data from size fractions (Kurnosov et al., this volume) does not distinguish zeolites. XRD data on zeolite separates is important to characterize better the mineralogical variations in the zeolites.

\section{Carbonate Cements}

In shipboard core observations, carbonate cement (excluding carbonate nodules) was identified in some sandstone beds between 220.4 and $405.5 \mathrm{mbsf}$ and in all sandstone-bearing cores below. The extent of carbonate cementation visible in the core is variable in any one specimen and is strongly controlled by the lithology/grain-size distribution. This variation is shown clearly in point-count data (Table 2, Fig. 3). Carbonate cements are particularly noticeable in the coarsegrained bases of Bouma A units and in coarse-grained burrows. Carbonate cement is present throughout the depth range of the steeply dipping domain (Table 1), although carbonate cements are not present 
in all samples and are less extensive in individual samples in which clay-zeolite cements are identified. Veins filled with carbonate are common below $405 \mathrm{mbsf}$, becoming numerous around a major fault at $687 \mathrm{mbsf}$ (Fig. 2). Carbonate probably makes up the cement to the fault breccia.

In many of the specimens examined using BSE and CL, the carbonate cement is zoned. CL images show patches of carbonate that luminesce very bright orange, enclosed in a darker orange carbonate that fills the majority of pores and pore throats. Two carbonate cements are observed only in specimens from shallower than 570 mbsf. The bright luminescing carbonate has a darker BSE intensity (Pl. 3, Figs. 3 and 4) and EDX analyses show that it contains minor components of both $\mathrm{Mn}$ and $\mathrm{Fe}$. The other carbonate is less rich in $\mathrm{Mn}$. The contacts between the two carbonate phases is sharp. Where carbonate cements infill foraminifers the compositions of carbonate cement contrast with that of the fossil. In CL images the fossils luminesce a darker orange than either of the cement phases. The fossils have a darker BSE signal than either cement phase, and EDX analyses indicate that the fossils are pure $\mathrm{CaCO}_{3}$.

A specimen at 427 mbsf contains a contact between a coarse and fine-grained sandstone. The color of the blue-dye impregnated hand specimen changes sharply across this bedding plane; the coarsegrained component is white, whereas the finer grained sediment is blue, reflecting significant porosity. BSE images (Pl. 3, Figs. 6 and 7) show that the coarser sandstone contains significant carbonate cement whereas the finer sandstone contains no carbonate cement, even adjacent to carbonate clastic components such as fossil fragments. The finer grained sandstone is better sorted and has a less diverse clast population compared with the coarser sandstone. Both have a filamentous clay/zeolite pore-filling cement (Pl. 3, Fig. 7). In the finer grained sandstone the clay/zeolite cement completely seals most of the throats between the pore spaces, and the remnant pores are mostly unconnected. In the coarser grained sandstone the pore throats are not clogged. The carbonate cement fills the porosity remnant from the clay/zeolite cement (Pl. 1, Fig. 6; and Pl. 3, Figs. 3 and 7) and clearly postdates the clay/zeolite cement. The pre-carbonate cement porosity and pore interconnectivity of the coarser grained sandstone is greater.

Wherever they coexist, carbonate cements postdate clay/zeolite cements (Pl. 2, Figs. 3 and 4) and the early cementation history is an important factor in controlling the extent of carbonate cements. Such controls are apparent on the fine scale; in Plate 2, Fig. 5, carbonate fills the secondary porosity after dissolution of a volcanic glassy fragment but has not filled a microporous volcanic lithic clast. In general, fine-grained specimens and specimens with extensive clay cements are not extensively carbonate cemented. In these specimens carbonate is confined to veins (Pl. 4, Figs. 1 and 2) and, less commonly, to breccias (Pl. 4, Fig. 3). Microscopic examination indicates that carbonate cements in most coarse-grained sandstones has a fracture geometry (Pl. 4, Fig. 4). Pervasive carbonate cementation is commonly developed across relatively small volumes corresponding to a length scale of a few millimeters to a few tens of centimeters. Within the zone of pervasive cements intragranular fractures filled with carbonate are observed locally. Toward the margins of the pervasively cemented volume the carbonate becomes restricted to a network of intergranular fractures (Pl. 4, Figs. 2 and 4), and less commonly intragranular fractures, with a preferred orientation. In one example, a carbonate vein with very sharp margins, in a fine-grained sediment, links to a volume of pervasive carbonate cementation within an adjacent coarsegrained sandstone (Pl. 4, Fig. 2).

\section{Three-dimensional Reconstruction of Carbonate Cement Geometries}

Many specimens, toward the base of the hole, contain small amounts of carbonate cement, which in two-dimensional sections lie in unconnected pore spaces. Three-dimensional reconstructions were made to establish whether the observation held in three dimensions. A
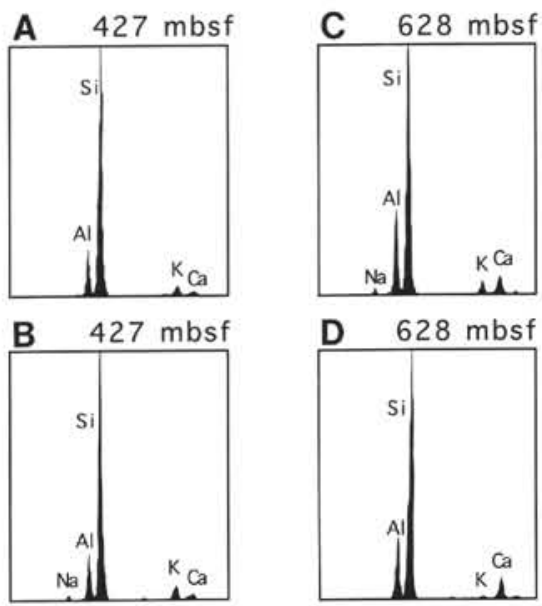

Figure 7. Examples of EDX spectra for zeolites from (A, B: clinoptilolite) 427 mbsf and (C, D: heulandite) 628 mbsf. Spectra have been normalized so that the silica peaks have the same height.

specimen from 668 mbsf illustrates typical results (Fig. 8). The carbonate cement is located in numerous, small isolated pore spaces less than $50 \mu \mathrm{m}$ in size, together with larger pore fillings with a variable degree of interconnectivity. The larger pores define linked tubules, commonly bifurcating or defining " $\mathrm{H}$ "-shaped structures. The smallest tubules are $160 \mathrm{~mm}$ in length and the largest are greater than the depth sampled within the specimen $(>280 \mathrm{~mm}$ ). Both the unconnected pores and tubules have sharp, angular contact relationships. There is apparently more out-of-section interconnectivity than in the plane of section, suggesting that interconnectivity is in the horizontal plane.

\section{Fe Sulfides}

Organic-rich muds between 47 and 104 mbsf are dominated by $\mathrm{Fe}$-sulfide. Framboidal Fe-sulfides are found associated with filamentous clay cements (Pl. 1, Fig. 4, and PI. 5, Fig. 1) and also within carbonate veins and cements. Framboids are clearly developed in compacted clastic grains (Pl. 5, Fig. 2) and may represent one of the earliest authigenic phases. There is a systematic change in sulfide mineralogy with depth. As yet this is only loosely documented. Purely framboidal Fe-sulfides persist to depths of about $600 \mathrm{mbsf}$ (Pl. 1, Fig. 4, and PI. 5 , Figs. 1 and 2). At about $630 \mathrm{mbsf} F e$-sulfides have framboidal cores and continuous, rounded (Pl. 5, Fig. 3), blocky (Pl. 5, Fig. 4), or spiky rims. This transition may represent a transition from framboidal to euhedral Fe-sulfide (Sawlowicz, 1993). The transition may also involve phase changes in the $\mathrm{Fe}-\mathrm{S}$ system that may be important in explaining variations in magnetic characteristics down the hole.

\section{Breakdown of Clastic Components}

Shipboard smear-slide studies (Behrmann, Lewis, Musgrave, et al., 1992) show that dissolution of amphibole and pyroxene, local micritization and recrystallization of nannofossils, and replacement of glassy fragments occurs from about $46 \mathrm{mbsf}$ to the base of the hole. At shallow levels, glassy fragments are replaced by clays whereas below $405.5 \mathrm{mbsf}$ replacement is by clays, carbonate, and zeolites.

Shorebased optical studies show that the dissolution of volcanic glass occurs as shallow as $20 \mathrm{mbsf}$ and is more or less ubiquitous deeper than 260 mbsf (Table 1). Dissolution of carbonate fossil tests occurs locally down to about $430 \mathrm{mbsf}$ and dissolution of amphibole/pyroxene occurs sporadically below $415 \mathrm{mbsf}$ (Pl. 2, Fig. 6). Feldspar dissolution is first observed clearly at 408.6 mbsf and is recognized in most samples down to the base of the hole. Feldspar dissolution is better developed at greater depths (Table 1). No silica cements or replacements are observed at any depth. Well preserved 


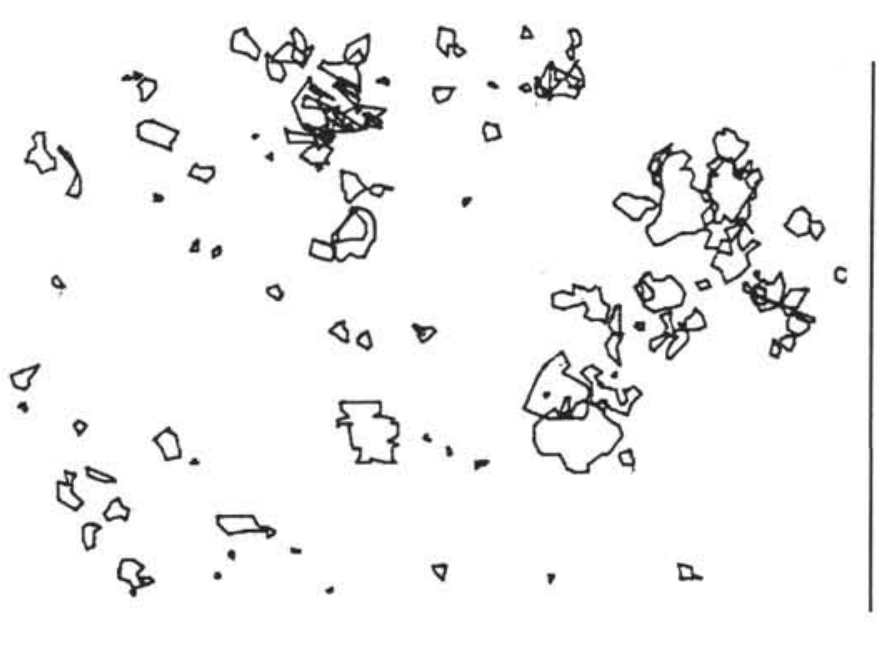

LEFT IMAGE

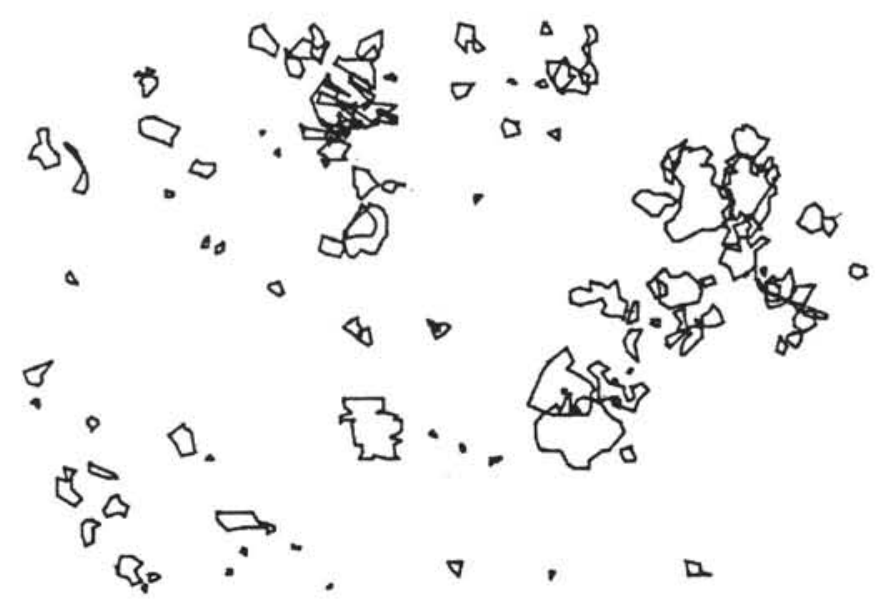

RIGHT IMAGE

$1 \mathrm{~mm}$

Figure 8. Stereopair image of three-dimensionally reconstructed carbonate cement pattern in a sandstone. These are best viewed by making a copy and separating the two halves to the optimal distance for your stereoviewer.

carbonate foraminifer tests are observed (PI. 5, Fig. 1) to the base of the hole.

Brown, intermediate to mafic volcanic glassy fragments (vitric and microlitic) appear to be especially susceptible to dissolution. The secondary pores are commonly defined by thin to discontinuous clay mineral rim cements or are fully or partly filled (Pl. 2, Fig. 3) with clay and zeolite cements. Shallower in the hole, where clay-zeolite cements are less extensive, some of the carbonate cements enclose euhedral plagioclase (Pl. 3, Fig. 5). The plagioclase laths are typically zoned and their distribution usually outlines the shape of a clast. We interpret these textures as indicative of partial dissolution of microlitic volcanic grains and infilling of the secondary porosity with carbonate cement. $\mathrm{K}$-feldspars are typically replaced by fine-grained mats of clays (PI. 5, Figs. 5 and 6), although this may represent pre-erosional weathering. In one sample, pores produced by the dissolution of mafic grains are filled with carbonate cement without the earlier zeolite cements (Pl. 2, Fig. 6). These data suggest that dissolution postdates the zeolite precipitation but predates carbonate cementation. Pores produced by the dissolution of plagioclase feldspar are not filled by later authigenic phases. This suggests that plagioclase feldspar dissolution was more extensive following clay mineral, carbonate, and zeolite cementation.

\section{DIAGENETIC EVOLUTION, PROCESSES, AND ENVIRONMENT}

Textural relationships clearly indicate that there are at least two phases of cementation: an early clay-zeolite cement and a later carbonate cement. The textures observed suggest that there is no overlap in time between these two phases within any given sample although it is possible that there has been a transition from clay-zeolite cementation at shallow depths to carbonate cementation deeper down and that the boundary between these has migrated upward with time. Fe-sulfides are associated with both of the cement phases. Some evidence suggests that during the early cement phase clay precipitation started before zeolite precipitation; clay mineral cements are commonly followed by zeolite cements within arc-related sequences (Marsaglia and Tazaki, 1992; Smith, 1991; Lee and Klein, 1986). Volcanic lithic clasts that are dissolved are infilled by both cement types, although replacement by carbonate cement is common only where the earlier cements are not well developed. This observation suggests that secondary porosity caused by the dissolution of volcanic lithic clasts developed before or during the early cementation phase. Data from the shallowest part of the hole may reflect the earliest diagenetic processes: dissolution of volcanic glass and the development of carbonate nodules. The general paragenetic sequence is shown in Figure 9, which also summarizes changes in diagenetic evolution with depth and postulates changes in diagenetic timing with depth.

The presence and composition of zeolites of the early cementation phase are strongly depth stratified. Given that the sediment composition does not change (Marsaglia et al., this volume), this suggests that pressure, temperature, and fluid parameters are controlling the zeolite stability and composition. Clinoptilolite (Schaller, 1932) is a highsilica type of heulandite (Hey and Bannister, 1934) and is a common authigenic mineral in volcaniclastics, usually formed soon after burial, with the breakdown of high-Si volcanic phases. The presence of clinoptilolite rather than other forms of zeolite implies high concentrations of silica in solution (Mumpton, 1977). With increasing depth, clinoptilolite breaks down again to lower-Si zeolites. It is significant that the diagenetic breaks at 407 and 473 mbsf (Table 1) correspond to significant changes in the pore-water geochemistry (Behrmann, Lewis, Musgrave, et al., 1992; Brown et al., this volume). At about $400 \mathrm{mbsf}$ there are significant inflections in $\delta^{18} \mathrm{O}, \mathrm{pH}, \mathrm{Na}$ and $\mathrm{Sr}$ with less marked change in $\mathrm{K}, \mathrm{Mg}$, and $\mathrm{Cl}$. Around $500 \mathrm{mbsf}$ there are significant inflections in $\delta^{18} \mathrm{O}, \mathrm{K}, \mathrm{Ca}, \mathrm{Mg}$, and $\mathrm{Sr}$. It is possible that the apparent zonation in the hole may be related to pore-water zonation rather than a function of burial/time, or that the current porewater fluid composition is controlled by downhole mineralogy. Clay zeolite cements are microporous, which may allow for open circulation and the exchange of cations with clays and zeolites. The zonation in clays and zeolites may well be a very recent phenomenon. Further quantification of the conditions associated with the changes in the zeolite composition and assemblage require more quantitative compositional data from electron microprobe or XRD studies.

In the late stages of diagenesis, impermeable layers are overcome by fracture processes, which suggests that fluid pressures must have been high. Carbonate cements in sandstones, which are developed in isolated pockets and in discrete volumes with fractured margins can be explained only by dilational disaggregation and subsequent collapse. This process also requires high fluid pressures. The microtexture shown in Plate 4, Fig. 2, is highly suggestive of dilation and cementation in the sands related to high fluid-pressure pulses fed through fracture systems. Data from deeper in Site 863 suggest that fluid flow here 


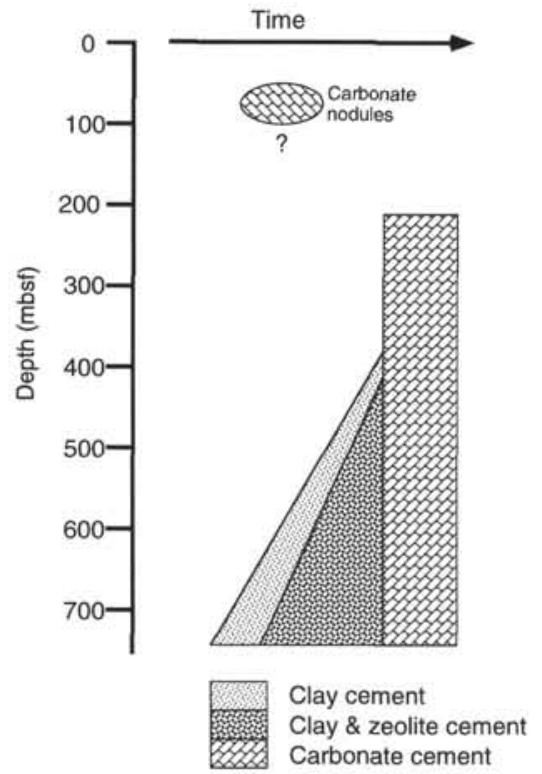

Figure 9. Schematic paragenetic sequence and its possible variation with depth. Diagram does not show the relative timing of grain dissolution or Fe-sulfide cements (throughout diagenetic history).

is dominantly horizontal, whereas higher up cross-cutting fracture systems point toward upward flow. Some carbonate cemented sandstones, particularly the coarser, more porous ones, do not show evidence of fracture/dilation (although transient dilation may have occurred and not be preserved). Dynamic permeability facilitated by fracture and dilation is likely to coexist with fluid flow through pore systems in the absence of dilation. The behavior of any individual specimen will depend upon its permeability in relation to the fluid-flow rate.

The sequence of Quaternary sediments, progressively indurated and cemented at Site 863 is highly unusual. Other Pleistocene-Quaternary forearc sections drilled by DSDP and ODP are unlithified and lack significant cementation (Marsaglia, 1989). This is due in part to the lower geothermal gradients normally found in forearc regions. The anomalous authigenic phases and diagenetic sequences found at Site 863 are therefore of interest in understanding the hydrothermal implications of spreading-ridge subduction along this margin. Although the early cementation is similar to that observed at Site 860 (Rochford et al., this volume), direct comparison is difficult because of the paucity of sand-sized sediment at Sites 859, 860, and 861. Filamentous smectites and framboidal Fe-sulfides are common components of the authigenic assemblages at Sites 860 and 863, together with the breakdown of volcanic glass (Marsaglia et al., this volume). However, neither zeolites nor carbonate cements have been identified at Site 860, either in shipboard smear slide studies or post-cruise work. The breakdown of volcanic glass and some clay cementation at Site 863 may relate to tectonic burial and dewatering processes prevalent during the development of the accretionary prism, before ridge collision. In contrast, the zeolite/clay and carbonate cements, which are unique to Site 863 within Leg 141 , are best explained by the location of this site above an active mid-ocean ridge. This is consistent with structural evidence that shows that the late carbonate cements correspond to a late-phase transtensional deformation (Behrmann, Lewis, Musgrave, et al., 1992) best associated with ridge subduction. Zeolite cements with downhole trends in zeolite mineralogy have also been observed in high heat-flow back-arc environments (e.g., Smith, 1991).

The fact that there are clear vertical changes in the clay-zeolite cement suggests then that the rotation of bedding to near vertical in the steeply dipping domain predates this cementation. It may be that the rotation of the bedding to the vertical needs to be explained within the framework of accretionary tectonics and not by some pecu- liarity associated with ridge subduction. Near-vertical bedding may have facilitated the subsequent alteration by focusing fluids up through this section.

One problem that needs explanation is how and why clay-zeolite cementation is superseded by carbonate cementation. One suggestion is that the two phases of cementation reflect different fluid sources. Perhaps the clay-zeolite cement is generated by convective recirculation of fluids from the accretionary prism under the thermal influence of the subducting mid-ocean ridge system or the young, hot crust which subducts prior to collision of the ridge-axis. Microtextural examination of contractional deformation structures at Site 863 (Agar and Prior, this volume) suggests that accretionary deformation continued during the precipitation of clay-zeolite cements. In contrast, the carbonate cementation is generally associated with extensional structures and may represent penetration of the prism by fluids from the mid-ocean ridge system itself, as a result of extension in the forearc above the ridge. The burial of a mid-ocean ridge and its associated active hydrothermal circulation under the accretionary prism is the easiest way to permeate the prism with pore fluids at high pressure and of a different composition to those in the prism. There is a problem in that changes in that the clay-zeolite cements correspond spatially to the pore-water profile anomalies identified by the geochemists (Behrmann, Lewis, Musgrave, et al., 1992; Brown et al., this volume). Distributions of carbonate cement, which is clearly the last cement phase, bears no obvious relationship to the pore-water geochemistry. One might envisage that the carbonate cementation is a short-lived event allowing fluid systems to return to equilibrium afterward. If this is the case, then it must be the downhole mineralogy controlling the pore-fluid chemistry. However, if the observed porefluid chemistry were controlling the precipitation of authigenic phases then one would expect a return to clay-zeolite cementation after the carbonate cementation event. This is not observed.

\section{ACKNOWLEDGMENTS}

Specimen preparation was conducted by Dave Oates at the British Geological Survey and at Geochem laboratories. Geoff Lloyd provided invaluable SEM advice. Steve Crowley assisted in CL analysis. Dave Bryon is thanked for help with 3-D reconstruction work. Jim Marshall and Flip Froehlich are thanked for advice on diagenetic processes throughout this project. Thorough reviews were provided by Peter Vrolijk and Alan Kemp. The international Ocean Drilling Program provided the samples. This research was funded through NERC grant GST/02/682.

\section{REFERENCES $*$}

Behrmann, J.H., Lewis, S.D., Musgrave, R.J., et al., 1992. Proc. ODP, Init. Repts., 141: College Station, TX (Ocean Drilling Program).

Goldstein, J.I., Newbury, D.E., Echlin, P., Joyce, D.C., Fiori, C., and Lifshin, E., 1981. Scanning Electron Microscopy and X-ray Microanalysis: New York (Plenum).

Güven, N., 1988. Smectites. In Bailey, S.W. (Ed.), Hydrous Phyllosilicates (exclusive of micas). Mineral. Soc., Am., Rev. Mineral., 19:497-559.

Hey, M.H., and Bannister, F.A., 1934. Studies on zeolites, Part VII: "clinoptilolite," a silica-rich variety of heulandite. Mineral. Mag., 23:556-572.

Lee, Y.I., and Klein, G. deV., 1986. Diagenesis of sandstones in the back-arc basins of the western Pacific Ocean. Sedimentology, 33:651-675.

Marsaglia, K.M., 1989. Petrography, provenance, and diagenesis of arc-related sands and sandstones [Ph.D. thesis]. Univ. of California, Los Angeles.

Marsaglia, K.M., and Ingersoll, R.V., 1992. Compositional trends in arc-related, deep-marine sand and sandstone: a reassessment of magmatic-arc provenance. Geol. Soc. Am. Bull., 104:1637-1649.

\footnotetext{
Abbreviations for names of organizations and publications in ODP reference lists follow the style given in Chemical Abstracts Service Source Index (published by American Chemical Society).
} 
Marsaglia, K.M., and Tazaki, K., 1992. Diagenetic trends in Leg 126 sandstones. In Taylor, B., Fujioka, K., et al., Proc. ODP, Sci. Results, 126: College Station, TX (Ocean Drilling Program), 125-138.

Mumpton, F.A., 1977. Mineralogy and geology of natural zeolites. Mineral. Soc. Am., Short Course Notes, 4.

Sawlowicz, Z., 1993. Pyrite framboids and their development: a new conceptual mechanism. Geol. Rundsch., 82:148-156.

Schaller, W.T., 1932. The mordenite-peilolite group: clinoptilolite, a new species. Am. Mineral., 10:305-325.

Smart, P., and Tovey, K., 1982. Electron Microscopy of Soils and Sediments: Techniques: Oxford (Oxford Univ. Press).
Smith, R.B., 1991. Diagenesis and cementation of lower Miocene pyroclastic sequences in the Sulu Sea, Sites 768, 769, and 771. In Silver, E.A., Rangin, C., von Breymann, M.T., et al., Proc. ODP, Sci. Results, 124: College Station, TX (Ocean Drilling Program), 181-199.

Welton, J.E., 1984. SEM Petrology Atlas. Methods Expl. Ser., AAPG.

Date of initial receipt: 19 July 1993

Date of acceptance: 29 July 1994

Ms 141SR-006 

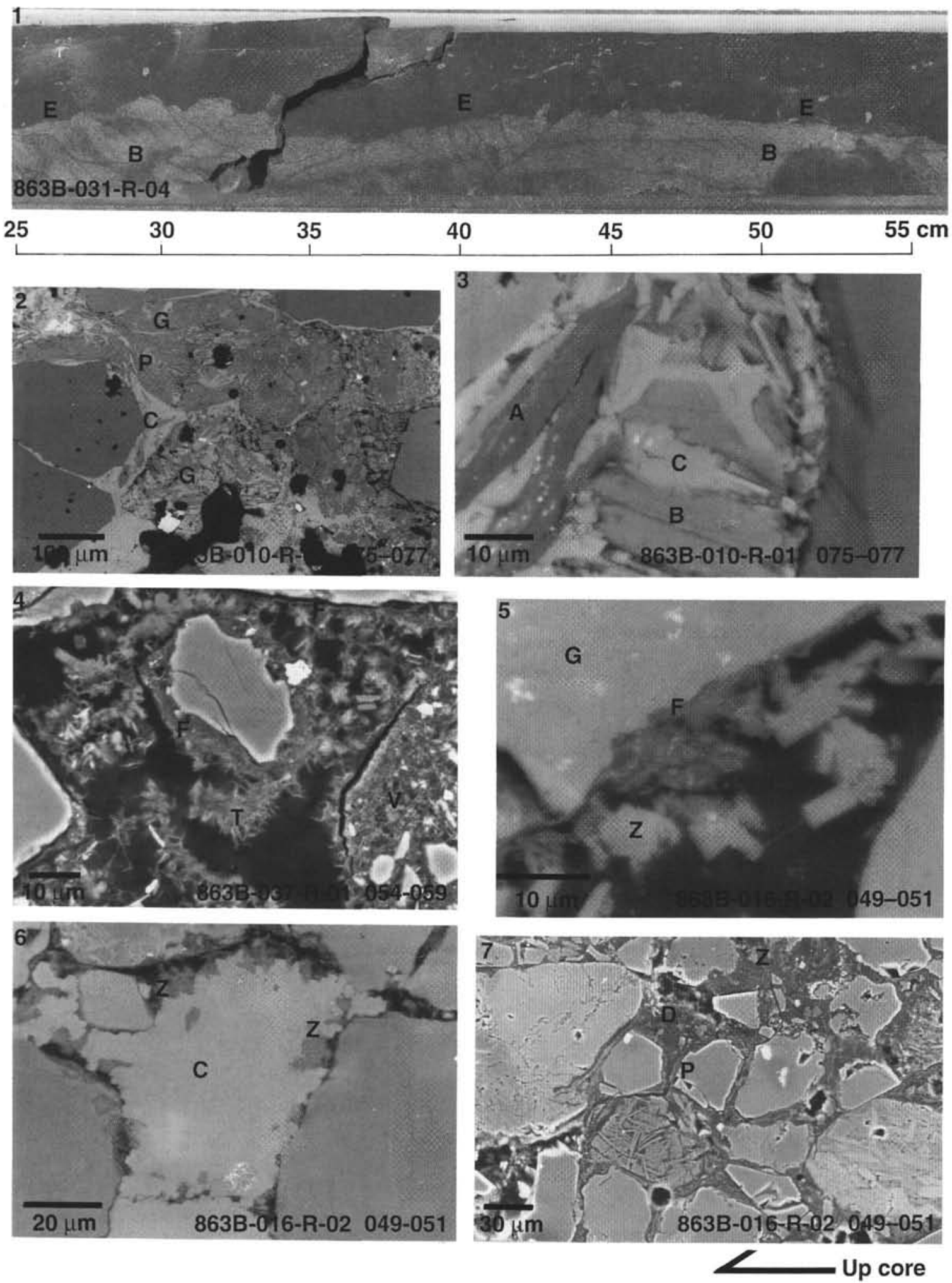

Plate 1. 1. Core photograph of erosively based sandstone layer (E), with bioturbation (B). 2. Blocky phyllosilicates (P) within carbonate cement (C). The phyllosilicate distribution outlines ghost clasts $(\mathrm{G})$. 3. Close up of 2. A dark phyllosilicate with intergrown lamellae of a light phyllosilicate (A) and vice versa (B), surrounded by paler carbonate cement (C). Position located on 2. 4. Filamentous clays coating clasts $(\mathrm{F})$ and associated with volcanic clasts (V). They also form tentacles grown into porosity (T). 5 . Aggregates of clay filaments (F) located along the boundaries of grains $(\mathrm{G})$, and supporting zeolite aggregates (Z). 6. Filamentous clays and zeolites (Z) located at grain boundaries. Most of the remaining porosity is infilled by carbonate cement (C). 7. A sample with little remaining porosity. Pore space has been occluded by a combination of pale grain-coating clays (P), a second darker clay (D), and small blocky zeolites (Z). There is no carbonate cement. 

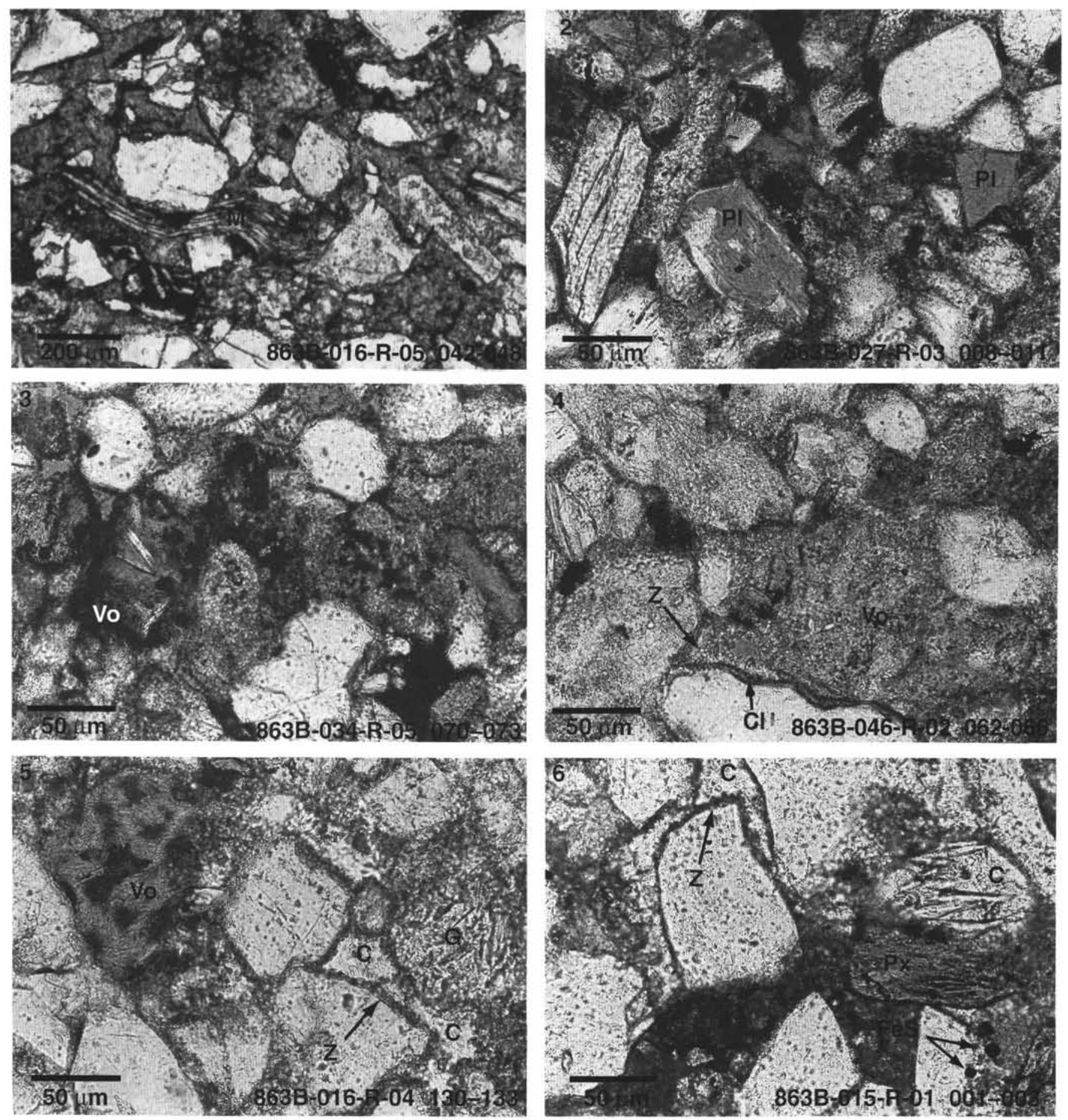

Plate 2. Optical photomicrographs of moderately to well-sorted sandstones impregnated with blue-dyed epoxy (porosity appears gray), all in plane polarized light. 1. Crenulated micas (e.g., M), deformed during compaction, may locally significantly reduce intergranular volumes prior to cementation. 2. Sandstone with pervasive clay cement (dark gray; dark green in plane polarized light) and secondary dissolution of plagioclase feldspar (PI). Note lack of authigenic clay minerals in secondary pores. Photograph taken in unstained part of slide. 3. Sandstone with clay cement (dark gray; dark green in plane polarized light) partially infilling dissolved microlitic volcanic lithic fragment (Vo). Light gray area surrounding white plagioclase microlites is residual secondary porosity. Photograph taken in unstained part of slide. 4. Sandstone exhibiting discrete clay rim cement ( $\mathrm{Cl}$; dark) followed by zeolite rim cement ( $\mathrm{Z})$, which partially infills pore space. Hazy grain (Vo) is a microporous, partially dissolved volcanic lithic fragment. Photograph taken in unstained part of slide. 5. Sandstone with zeolite rim cement (Z) followed by pore-filling carbonate cement (C). Carbonate has filled secondary porosity produced by dissolution of volcanic glassy fragment (G), but has not filled the microporous volcanic lithic fragment (Vo), which has partially altered to clay minerals (dark gray; dark green in plane polarized light). Photograph taken in stained part of slide, and zeolite cement is stained red (Ca)/yellow (K). 6. Sandstone with early zeolite rim cement (Z) followed by carbonate pore-filling cement (C). Pyroxene crystal ( $\mathrm{Px})$ is partially dissolved and exhibits cockscomb texture; secondary pore has been infilled with carbonate cement. Lack of zeolite rim in secondary pore suggests pyroxene dissolution occurred after zeolite cementation, but prior to carbonate cementation. Fe-sulfide framboids (FeS) are included in and therefore predate carbonate cement. Dark irregular patch at bottom of photograph is a deformed sedimentary lithic fragment. Photograph taken in stained part of slide, and zeolite cement is stained red $(\mathrm{Ca}) /$ yellow $(\mathrm{K})$. 

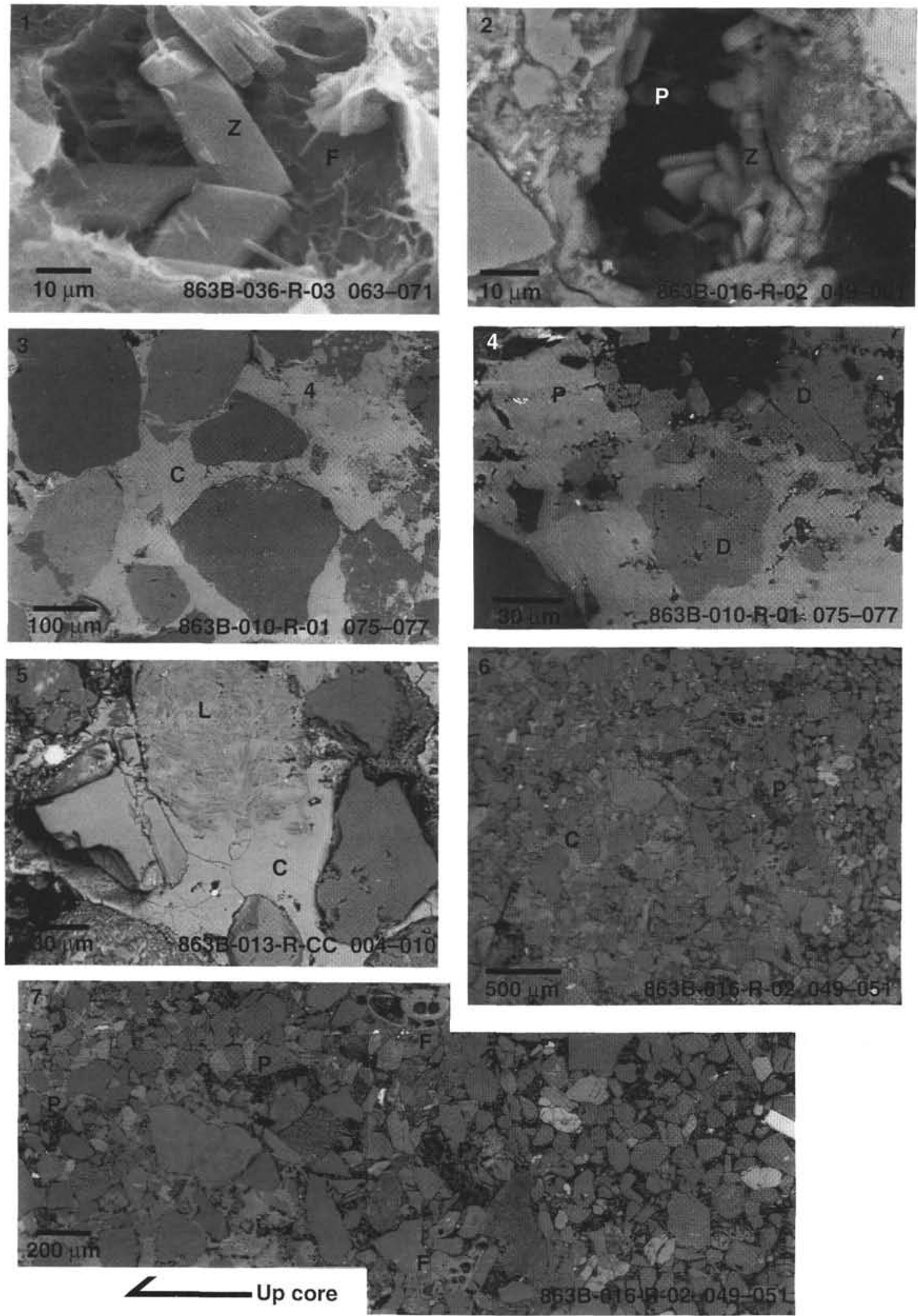

Plate 3. 1. SE image of brick-like zeolites $(\mathrm{Z})$ suspended by filamentous clays (F). 2. SE image of blocky zeolites (Z) grown into a pore space (P). 3. Sample with a well-developed carbonate cement (C). 4. Close up of carbonate cement in 3 showing zoning between pale (P) and dark (D) carbonate cement. Position located on 3. 5. A single carbonate cement (C) with inclusions of plagioclase laths (L) that outline the shape of a clast. 6. Contact between a coarser grained sandstone with carbonate cement (C) and a finer grained sandstone without carbonate cement and with some remaining porosity $(\mathrm{P})$. 7. Close up of 6 . There is no carbonate cement developed on the right-hand side, even adjacent to carbonate fossils (F). Both sides have clays and zeolites in the pore spaces $(\mathrm{P})$. 

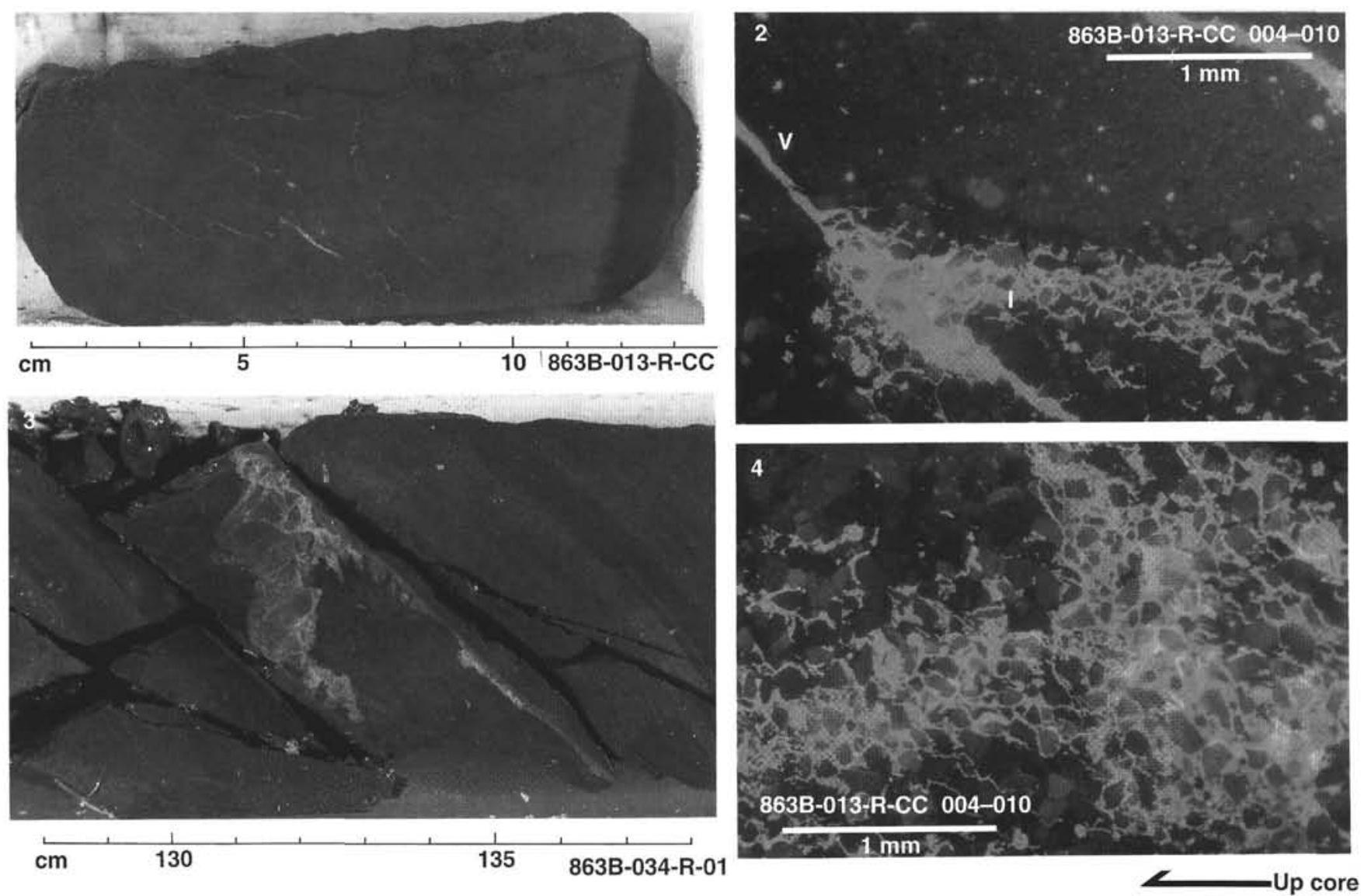

Plate 4. 1. Core photograph of irregular carbonate veins. The dark blebs in the cores of the veins are aggregates of Fe-sulfide and quartz. 2. CL photographs of a carbonate vein (V) in a fine-grained layer linked to a more pervasive network of intergranular fractures in a coarser-grained layer (I). 3. Core photograph of a small fault-block breccia cemented by carbonate. 4 . A pervasively cemented coarse-grained layer linked to a restricted network of intergranular fractures on the left-hand side. 

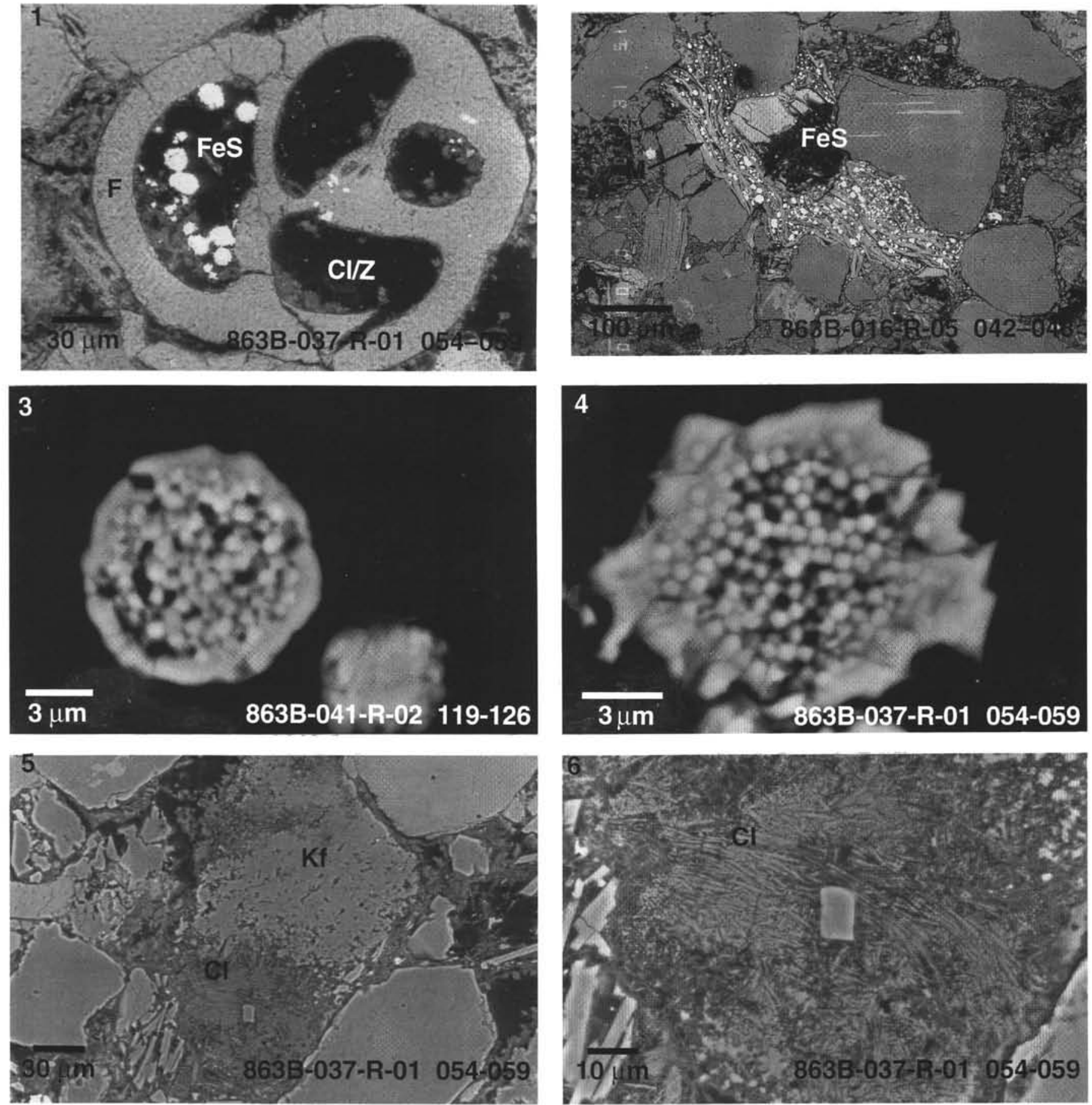

Plate 5. 1. Carbonate foraminifer test (F), showing no dissolution or replacement. The fossil has an intergrown cement of filamentous clays with some zeolites $(\mathrm{Cl} / \mathrm{Z})$, which rims the outer surface and partly infills the pores. Framboidal Fe-sulfide $(\mathrm{FeS})$ is associated with this cement in at least two pores. 2. Compaction-related crenulation of detrital mica (M). Growth of framboidal Fe-sulfides ( $\mathrm{FeS}$ ) in the mica cleavage plane suggests that they formed early in the diagenetic history. 3. Fe-sulfides with framboidal cores and continuous rounded margin. 4. Fe-sulfides with framboidal cores and blocky/spiky margin. 5. Filamentous and feathered clays $(\mathrm{Cl})$ replacing a K-feldspar clast (Kf). 6. Close up of 5. 